\title{
Keterampilan Dan Etika Komunikasi Islami Antarpribadi Di Dalam Buku Enjoy Your Life Karya Dr. Muhammad Al-Areifi
}

\author{
M. Toha \\ UIN Antasari Banjarmasin
}

\begin{abstract}
The ability to communicate interpersonally is a very important skill for anyone. This is because everyone needs to establish a harmonious relationship with other fellow human beings. However, the fact that communication is not something that is easy. Therefore, we must do various efforts to improve our communication skills. in addition we must also study the ethics of communication as our basic principle in communicating. one of the best sources of communication skills is the Qur'an and Sunnah of Prophet Muhammad s.a.w. One of the books that the authors assume summarizes the skills and ethics of interpersonal communication is Dr. Enjoy Your Life's book. Muhammad Al Areifi. Departing from these assumptions, the authors decided to conduct in-depth research on the book using qualitative content analysis methods and it was answered that the book is indeed loaded with a summary of skills and communication ethics according to the Qur'an and sunnah. Among the results of the study on Enjoy Your Life the author found 11 skill subcategories with 290 skill points and 7 categories of ethics with 111 ethical points. From the research the writer can conclude that there are many skills and ethics of interpersonal Islamic communication that can make us good communicator.
\end{abstract}

Keywords: skills, ethics of islamic communication, enjoy your life 


\section{Pendahuluan}

Berkomunikasi antarpribadi, atau secara ringkas berkomunikasi, merupakan keharusan bagi manusia. Manusia membutuhkan dan senantiasa berusaha membuka serta menjalin komunikasi atau hubungan dengan sesamanya. Selain itu, ada sejumlah kebutuhan di dalam diri manusia yang hanya dapat dipuaskan lewat komunikasi dengan sesamanya.

\begin{tabular}{l}
\multicolumn{3}{c}{ Komunikasi antarpribadi } \\
sangat penting bagi kebahagiaan \\
hidup kita. Jhonson $\quad(1981)$ \\
menunjukkan beberapa peran yang \\
disumbangkan oleh komunikasi \\
antarpribadi dalam rangka \\
menciptakan kebahagiaan hidup \\
manusia.
\end{tabular}

Pertama, $\quad$ komunikasi antarpribadi membantu perkembangan intelektual dan sosial kita. Kedua, identitas atau jati diri kita terbentuk dalam dan lewat komunikasi dengan orang lain.Ketiga, dalam rangka memahami realitas di sekeliling kita serta menguji kebenaran kesan-kesan dan pengertian yang kita miliki tentang dunia di sekitar kita. Keempat, kesehatan mental kita sebagian besar juga ditentukan oleh kualitas komunikasi atau hubungan kita dengan orang lain, lebih-lebih orangorang yang merupakan tokoh-tokoh signifikan (significant figures) dalam hidup kita.

Agar merasa bahagia, kita membutuhkan konfirmasi dari orang lain, yakni pengakuan berupa tanggapan dari orang lain yang menunjukkan bahwa diri kita normal, sehat, dan berharga. Lawan dari konfirmasi adalah diskonfirmasi, yakni penolakan dari orang lain berupa tanggapan yang menunjukkan bahwa diri kita abnormal, tidak sehat dan tidak berharga. Semuanya itu hanya kita peroleh lewat komunikasi antarpribadi, komunikasi dengan orang lain . (Supratiknya, 1995).

Agar mampu memulai, mengembangkan dan memelihara komunikasi yang akrab, hangat, dan produktif dengan orang lain, kita perlu memiliki sejumlah keterampilan dasar dan etika dalam berkomunikasi. Ada beberapa buku-buku yang menjelaskan dan menguraikan keterampilan dan etika dalam 
berkomunikasi. Dari yang berbahasa indonesia sampai dengan yang berbahasa asing. namun kebanyakan buku-buku itu sebagian hanya berisi teori-teori tanpa ada contoh nyata berdasarkan dari pengalaman sipenulis atau tokoh-tokoh terkenal yang dikutip si-penulis sehingga menjadikan buku-buku tersebut kurang berbobot. Selain itu, saya yang notabene orang indonesia dan beragama islam dan banyak lagi orang indonesia lainnya yang beragama islam belum banyak memiliki referensi berupa buku yang menjabarkan secara terperinci keterampilan dan etika berkomunikasi yang sesuai dengan ajaran islam yang berdasarkan alqur'an dan as-sunah.

Ada sebuah buku yang sangat bagus yang merupakan buku best seller yang telah dicetak lebih dari tiga juta eksemplar dan telah diterjemahkan kedalam 11 bahasa asing. Buku tersebut menurut asumsi penulis sarat dengan materi yang memaparkan keterampilan dan etika berkomunikasi yang sesuai syariat islam, khususnya adalah keterampilan dan etika berkomunikasi antarpribadi. Buku tersebut berjudul ENJOY YOUR LIFE yang merupakan terjemahan dari buku yang berjudul ISTAMTI' BIHAYATIK yang ditulis oleh Dr. Muhammad Al-Ariefi. Buku tersebut diterjemahkan kedalam bahasa Indonesia oleh Zulfi Askar dan diterbitkan pada bulan februari tahun 2008 oleh penerbit Qishti Press.

Sangat menarik dari buku ini adalah hampir setiap bab atau judul pembahasan di dalam buku ini di dukung dengan kisah-kisah yang terjadi di zaman Nabi Muhammad Shollallahu 'alaihi wasallam baik yang dialami Nabi Muhammad Shollallahu 'alaihi wasallam sendiri atau sahabat-sahabat beliau rodhiallahu 'anhum ajma'in yang menggambarkan bagaimana mereka berkomunikasi dalam kehidupan sehari-hari dan banyak juga cerita pengalaman langsung si penulis yaitu Dr. Muhammad Al-Ariefi yang telah menerapkan tehnik-tehnik yang dipaparkan di dalam buku ini. Selain itu juga ada kisah-kisah nyata berupa kejadian yang terjadi di sekitar beliau yang berkaitan dengan pembahasan. 
Buku tersebut ditulis dengan bahasa yang ringan dan sangat mudah difahami oleh siapa saja yang bisa membaca. Buku tersebut juga didukung dengan gaya bahasa yang dapat menyentuh hati pembacanya. Hal luar biasa yang dirasakan oleh penulis setelah membaca buku ini adalah munculnya motivasi untuk memperbaiki hidup agar hidup terasa lebih bahagia, nikmat dan bermakna.

Dari latar belakang tersebut penulis merasa tertantang untuk melakukan penelitian dan analisa mendalam terhadap buku dengan tujuan menengetahui keterampilan komunikasi islami antarpribadi di dalam buku Enjoy Your Lif dan etika komunikasi antar pribadi di dalam buku Enjoy Your Life.

\section{Pembahasan}

\section{A. Keterampilan Komunikasi}

Komunikasi adalah aktivitas utama manusia dalam kehidupan sehari-hari, baik itu komunikasi dengan Tuhan, sesama manusia, dan makhluk lainnya. Komunikasi merupakan modal dan kunci sukses dalam pergaulan dan karier karena hanya dengan komunikasi sebuah hubungan baik dapat dibangun dan dibina. Dalam konteks tertentu, berkomunikasi memerlukan skill (keterampilan) yang harus dilatih dan dikembangkan.

Keterampilan komunikasi adalah keterampilan yang harus dimiliki oleh seorang komunikator agar komunikasi yang dilakukannya berjalan dengan baik dan sesuai dengan maksud dan tujuan yang diharapkan.

Keterampilan komunikasi seperti jurnalistik/menulis dan public speaking selalu dibutuhkan dalam banyak bidang pekerjaan, bahkan menjadi karier tersendiri seperti wartawan, penyiar, MC, trainer, dan humas (public relations). Keterampilan komunikasi juga dibutuhkan dalam pengembangan usaha menjalin relasi, marketing, promosi dan lainlain, juga dalam pengembangan dan pemberdayaan diri personal branding/self empowering.

Keterampilan komunikasi
adalah keterampilan utama yang
harus dimiliki untuk mampu
membina hubungan yang sehat di


mana saja, di lingkungan sosial, sekolah, usaha, dan perkantoran atau di masyarakat (http://shannonweaver-ppmb2013).

\section{Pembagian}

Keterampilan

\section{Komunikasi}

Keterampilan Komunikasi (Communications Skill) dapat dibagi dalam tiga kategori:

- Keterampilan komunikasi lisan

- Komunikasi tulisan

- Komunikasi non-verbal.

Komunikasi lisan meliputi penyajian, pemahaman karakter audiens, mendengar secara kritis, dan bahasa tubuh. Komunikasin oral adalah kemampuan untuk menjelaskan dan mempresentasikan ide secara lisan dalam bahasa yang jelas kepada khalayak yang beragam. Kemampuan ini mencakup kemampuan untuk mengemas kata-kata, menggunakan gaya dan pendekatan yang tepat, dan pemahaman tentang pentingnya isyarat non-verbal dalam komunikasi lisan. Teknik komunikasi oral dikembangkan dalam ilmu/teknik public speaking, presentasi, dan siaran radio/televisi.

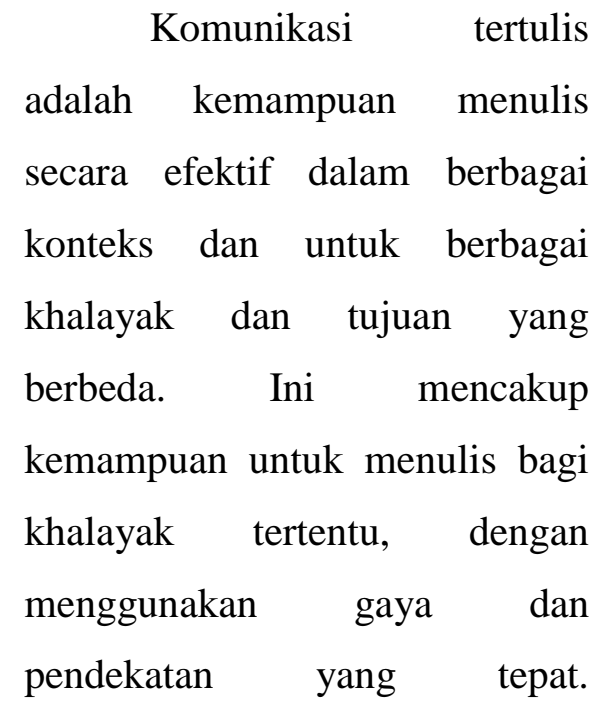

Komunikasi tertulis memerlukan keterampilan latar belakang (background skills) seperti menulis akademis, mengedit, membaca secara kritis, dan pengajian data. Hal ini juga meliputi komunikasi elektronik, seperti SMS, email, forum diskusi online, chat room, dan pesan instan (instant messaging).

$$
\text { Komunikasi non- }
$$
verbaladalah kemampuan untuk mengekspresikan ide dan konsep melalui penggunaan bahasa tubuh, gerak tubuh, ekspresi wajah, dan nada suara, juga penggunaan gambar, ikon, dan 
simbol. Komunikasi non-verbal meliputi pemahaman audiens, presentasi personal, dan bahasa tubuh (http://shannonweaverppmb, 2013)

\section{Keterampilan}

Komunikasi Antarpribadi

Komunikasi antarpribadi adalah sesuatu yang tidak bisa dipisahkan dari kehidupan manusia. Berkomunikasi adalah kebutuhan pokok bagi manusia selain pangan, sandang dan papan. Karena dengan komunikasilah banyak kebutuhan pokok lain dapat terpenuhi, seperti kebutuhan sosial dan emosional.

Akan tetapi pada
realitanya, komunikasi yang
dilakukan setiap orang berbeda-
beda dalam aspek keefektifan dan
baik-buruknya. Terkadang ada
orang yang baik dan efektif
komunikasinya dan ada pula yang
buruk dan tidak efektif. Itu semua
tergantung kepada kemampuan
berkomunikasi antarpribadi yang
dimiliki oleh seseorang.

Kemampuan

berkomunikasi antarpribadi adalah salah satu keterampilan yang sangat penting bagi siapapun, baik seorang pemimpin maupun rakyat biasa. Hal ini disebabkan setiap orang perlu menjalin hubungan harmonis dan kerjasama dengan orang lain untuk mencapai tujuan tertentu. Dalam suasana aktivitas di tempat kerja, komunikasi interpersonal sangat diperlukan sebagai upaya untuk menjaga kualitas hubungan antarmanusia, baik internal maupun eksternal. Hubungan secara internal berarti melibatkan orang-orang dari sebuah perusahaan atau lembaga yang sama, sedangkan hubungan eksternal berarti melibatkan pihak-pihak yang berada di luar institusi tempat kerja. Sesama karyawan maupun sesama teman tentu saling memerlukan hubungan dan ikatan emosional. Setiap orang memerlukan pengakuan dari orang lain (Suranto, 2011).

Dalam kehidupan seharihari pun banyak kegagalan dalam pekerjaan atau karier disebabkan kegagalan berkomunikasi. 
Misalnya, orang tidak diterima bekerja karena ia gagal berkomunikasi dalam wawancara. Mungkin ia arsitek yang cerdas atau akuntan yang brilian, namun ia tidak dapat "menjual" dirinya di hadapan pewawancara. Manajer dipecat dari jabatannya karena ia gagal berkomunikasi dengan bawahan. Seorang wakil rakyat gagal dipilih kembali karena ia gagal berkomunikasi dengan konstituennya. Seorang diplomat gagal meyakinkan negri tempat ia ditugaskan karena ia bukan hanya tidak persuasif, bahkan tidak menguasai bahasa setempat secara optimal. Bahkan seorang peneliti yang sepanjang tahun bekerja di sebuah laboratorium terpencil pun bisa gagal kalau ia tidak mampu mengkomunikasikan temuannya dalam seminar atau tulisan dalam media cetak. Ada kalanya orang pun gagal berkomunikasi dengan sesama anggota keluarga: ibu yang tidak dapat berkomunikasi dengan anak-anaknya, atau anakanak yang tidak dapat berkomunikasi dengan ayahnya.
Bahkan dalam dunia lawak pun, para pelawak yang gagal berkomunikasi beresiko ditinggalkan penonton, dicemoohkan, untuk kemudian dilupakan. Sedangkan para pelawak yang terampil berkomunikasi seperti Miing Bagito dan Eko Patrio terus berkibar dan dibutuhkan orang, dan dibayar berapa pun sesuai dengan permintaan mereka. dalam konteks inilah kita harus menegaskan kembali persepsi kita bahwa komunikasi itu bukan sesuatu yang mudah. Karena itu, berbagai upaya terus menerus harus kita lakukan untuk meningkatkan pengetahuan komunikasi kita dan keterampilan kita berkomunikasi. Mestinya tidak ada kata berhenti dalam belajar, karena pengetahuan dan keterampilan yang kita butuhkan harus selalu kita asah, agar senantiasa up-to-date dan sesuai dengan perkembangan masyarakat dan wacana mereka (Mulyana, 2011).

Agar mampu memulai, mengembangkan dan memelihara 
komunikasi yang akrab, hangat, dan produktif dengan orang lain, kita perlu memiliki sejumlah keterampilan dasar berkomunikasi. Menurut Johnson (1981), beberapa keterampilan dasar yang dimaksud adalah sebagai berikut.

Pertama, kita harus mampu saling memahami. Secara rinci, kemampuan ini mencakup beberapa subkemampuan, yaitu sikap percaya, pembukaan diri, keinsafan diri dan penerimaan diri (Johnson, 1981).

Agar dapat saling memahami, kita harus saling percaya. Sesudah saling percaya, kita harus saling membuka diri, yakni saling mengungkapkan tanggapan kita terhadap situasi yang sedang kita hadapi, termasuk kata-kata yang diucapkan atau perbuatan yang dilakukan oleh lawan komunikasi kita. untuk dapat membuka diri seperti itu, tentu saja sebelumnya kita harus menginsafi diri kita, yaitu menyadari perasaan-perasaan kita maupun tanggapan-tanggapan batin lainnya. Namun, untuk dapat sampai pada keinsafan diri semacam itu, kita perlu menerima diri, menerima dan mengakui perasaan-perasaan kita, bukan menyangkal, menekan, atau menyembunyikannya. Selain itu, tentu saja kita juga harus mempu mendengarkan orang lain. membuka diri kepada orang lain dan mendengarkan dengan penuh perhatian ketika orang lain sedang membuka diri kepada kita adalah cara yang jitu untuk memulai dan memelihara komunikasi (Johnson, 1981).

Kedua, kita harus mampu mengkomunikasikan pikiran dan perasaan kita secara tepat dan jelas. Kemampuan ini juga harus disertai kemampuan menunjukkan sikap hangat dan rasa senang serta kemampuan mendengarkan dengan cara yang akan menunjukkan bahwa kita memahami lawan komunikasi kita. Dengan saling mengungkapkan pikiran-perasaan dan saling mendengarkan, kita memulai, mengembangkan, dan memelihara komunikasi dengan orang lain. 
Ketiga, kita harus mampu saling menerima dan memberikan dukungan atau saling menolong. Kita harus mampu menanggapi keluhan orang lain dengan caracara yang bersifat menolong, yaitu menunjukkan sikap memahami dan bersedia menolong sambil memberikan bimbingan dan contoh seperlunya, agar orang tersebut mampu menemukan pemecahanpemecahan yang konstruktif terhadap masalahnya.

Keempat, kita harus mampu memecahkan konflik dan bentuk-bentuk masalah antarpribadi lain yang mungkin muncul dalam komunikasi kita dengan orang lain, melalui caracara yang konstruktif. Artinya, dengan cara-cara yang semakin mendekatkan kita dengan lawan komunikasi kita dan menjadikan komunikasi kita semakin tumbuh dan berkembang. Kemampuan ini sangat penting untuk mengembangkan dan menjaga kelangsungan komunikasi kita (Supratiknya, 1995).
Dari beberapa penjabaran tentang keterampilan komunikasi oleh para ahli di atas, penulis mengambil kesimpulan bahwa keterampilan komunikasi antarpribadi adalah kemampuan untuk memulai, mengembangkan, dan memelihara komunikasi yang akrab, hangat, dan produktif dengan orang lain, serta kemampuan untuk mengurangi atau menghilangkan kegagalan komunikasi sehingga komunikasi tersebut menjadi komunikasi yang sangat efektif dan mampu mencapai tujuan.

\section{Etika Bergaul}

Di dalam kamus besar bahasa Indonesia kata gaul diartikan sebagai: hidup berteman (bersahabat) (http://kbbi.web.id). Bergaul merupakan kegiatan yang dilakukan manusia untuk menjalin hubungan dengan manusia lainnya. Dunia yang berisi hubungan dengan sesama manusia disebut dengan pergaulan. Pergaulan merupakan 
jalinan hubungan sosial antara seseorang dengan orang lain yang berlangsung dalam jangka relatif lama sehingga terjadi saling mempengaruhi satu dengan lainnya.

Pergaulan merupakan kelanjutan dari proses interaksi sosial yang terjalin antara individu dalam lingkungan sosialnya. Kuat lemahnya suatu interaksi sosial mempengaruhi erat tidaknya pergaulan yang terjalin. Seorang anak yang selalu bertemu dan berinteraksi dengan orang lain dalam jangka waktu relatif lama akan membentuk pergaulan yang lebih. Beda dengan orang yang hanya sesekali bertemu atau hanya melakukan interaksi sosial secara tidak langsung

(https://id.wikipedia.org). Jadi bergaul adalah suatu hal yang tidak dapat dipisahkan dari manusia normal, dan di dalam bergaul pasti ada komunikasi yang terjalin di dalamnya yang berarti harus ada juga aturanaturan yang bisa mengontrol pergaulan itu agar tidak merugikan pelakunya.

Ada 47 poin etika komunikasi yang termasuk sub kategori etika bergaul, beberapa di antaranya penulis analisa sebagai berikut:

a. Bergaul dengan siapa saja dan kapan saja dengan akhlak yang mulia sehingga akhlak mulia menjadi ciri dan pembawaan diri Anda.

Bergaul adalah hal yang mutlak harus dilakukan oleh manusia, karena dengan bergaul, seorang manusia bisa membangun hubungan yang baik dengan lingkungannya dan bisa memberikan manfaat atau mendapatkan manfaat darinya. Di dalam bergaul hendaknya kita tidak pilihpilih atau hanya bergaul dengan orang-orang tertentu saja. Kita harus bisa membawa diri di dalam pergaulan kita. apabila kita bergaul dengan orang-orang yang buruk maka kita harus bisa membatasi pengaruh 
buruk dari pergaulan tersebut dan berusaha untuk memberikan pengaruh positif kepada orang-orang tersebut. Dan apabila kita bergaul dengan orang-orang yang baik maka kita harus berupaya saling berbagi kebaikan dengan mereka.

Yang paling utama dan harus kita lakukan di dalam pergaulan adalah membekali diri kita dengan akhlak yang mulia sehingga akhlak tersebut dapat memberi manfaat bagi orang lain dan menjadi ciri khas dan karakteristik diri kita. Rasulullah s.a.w. adalah pribadi yang paling berakhlak di dalam pergaulan beliau. Sehingga kita sebagai umat beliau harus mencontoh beliau di dalam bergaul dengan siapa saja. Karena bergaul dengan manusia dengan akhlak mulia adalah salah satu dari perintah beliau. Sebagaimana disebutkan di dalam sebuah hadits yang berbunyi:

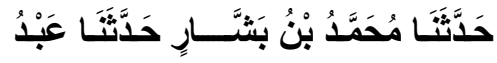

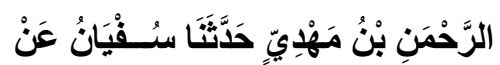

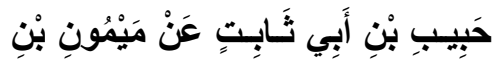

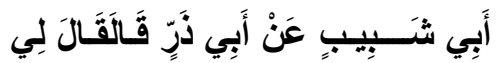

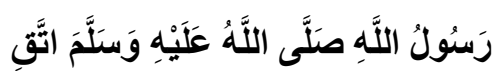

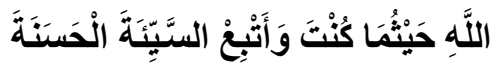

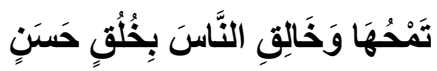

Muhammad bin Basysyar menceritakan kepada kami, Abdurrahman bin Mahdi menceritakan kepada kami, Sufyan menceritakan kepada kami, dari Hubaib bin Abu Tsabit, dari Maimun bin Abu Syaib, dari Abu Dzar, ia berkata, Rasulullah SAW bersabda kepadaku, "Bertakwalah engkau kepada Allah dimana pun engkau herada. Ikutilah (perbuatan) yang huruk dengan (perbuatan) yang baik, niscaya -perbuatan yang baik itu- akan menghapus perbuatan yang buruk. Dan, gaulilah manusia dengan budi pekerti yang baik'. " (HR. Tirmidzi)

Dari hadits tersebut dapat kita pahami bahwa Rasulullah s.a.w. telah memerintahkan kepada kita untuk selalu menggauli manusia dengan akhlak yang baik. 
b. Bersikap ramah kapan saja dan terhadap siapa saja.

Telah banyak penulis jelaskan pada pembahasan sebelumnya tentang anjuran untuk bersikap ramah dengan siapa saja dan kapan saja. Dan termasuk di dalam pergaulan kita sehari-hari dengan orangorang di sekitar kita. Sikap ramah terhadap orang lain adalah sebuah kewajiban bagi kita, karena keramahan di dalam bergaul telah dicontohkan oleh Rasulullah s.a.w. dan sudah menjadi keharusan bagi kita umat beliau untuk mengikuti apa yang beliau contohkan. Selain itu mengikuti keramahan Rasulullah di dalam bergaul juga merupakan bentuk kecintaan kita kepada Allah s.w.t. sebagaimana yang dijelaskan di dalam firmanNya yang berbunyi :

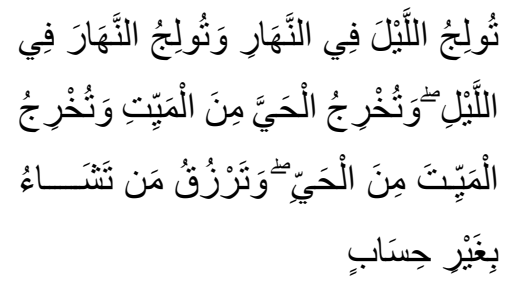

Katakanlah: "Jika kamu (benar-benar) mencintai Allah, ikutilah aku, niscaya Allah mengasihi dan mengampuni dosa-dosamu". Allah Maha Pengampun lagi Maha Penyayang.

Maka dari itu kita harus selalu mengikuti akhlak Rasulullah di dalam pergaulan termasuk di dalamnya keramahan beliau kepada siapa saja. Dengan usaha mengikuti Rasulullah s.a.w. tersebut kita berharap Allah s.a.w. akan mengampuni dosa-dosa yang pernah kita lakukan.

\section{c. Menghormati orang lain.}

Sering kita mendengar nasihat guru-guru kita di sekolah dulu ketika kita ribut dan tidak memperhatikan pelajaran yang beliau berikan. Beliau berkata di dalam nasihatnya "Hormati orang lain bila kamu ingin dihormati orang lain". memang benar nasihat yang disampaikan oleh para guru tersebut. Namun yang perlu kita 
ketahui bahwa menghormati orang lain adalah kewajiban kita sebagai seorang muslim. Meskipun orang lain tidak menghormati kita maka tetap wajib bagi kita untuk menghormati orang tersebut. Sebagaimana yang dijelaskan oleh Rasulullah s.a.w. di dalam sabdanya yang berbunyi :

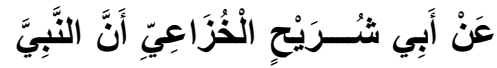

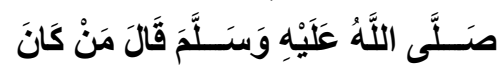

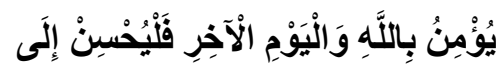

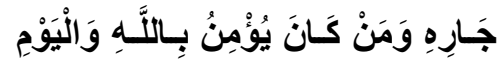

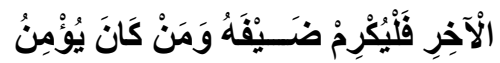

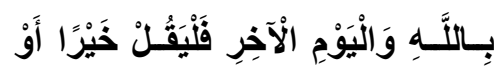
لِيَسنْكُتْنْ

Dari Abu Syuraih Al Khuza'i RA, bahwasanya Rasulullah SAW bersabda, "Barang siapa yang beriman kepada Allah dan hari Akhir, hendaklah ia berlaku baik terhadap tetangganya. Barang siapa beriman kepada Allah dan hari akhir, hendaklah ia menghormati tamunya. Dan barang siapa beriman kepada Allah dan hari akhir, hendaklah ia berbicara yang baik atau diam" (HR.Muslim)

Tamu yang mungkin bukan orang yang dekat atau mungkin tidak kenal dengan kita saja Rasulullah s.a.w perintahkan kita untuk menghormati mereka. apalagi orang-orang yang dekat dengan kita atau orang-orang di sekeliling kita tentunya lebih berhak dan wajib kita hormati.

d. Memperlakukan setiap orang dengan baik dan tidak membeda-bedakan mereka

Sering kali kita membeda-bedakan perlakuan kita terhadap orang-orang di sekitar kita tergantung kepada kecintaan kita kepada mereka. orang-orang yang kita cintai cenderung kita perlakukan dengan baik, sedangkan orang-orang yang kita benci kita perlakukan dengan buruk. Padahal perilaku membedabedakan tersebut sebenarnya adalah hal yang tidak seharusnya kita lakukan. Karena kita sebagai seorang muslim diperintahkan oleh Allah untuk memperlakukan 
setiap orang dengan baik tanpa membeda-bedakan mereka. sebagaimana Allah s.w.t. berfirman di dalam sebuah ayat yang berbunyi :

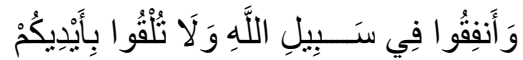

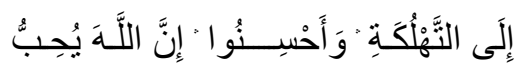

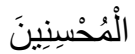

Dan belanjakanlah (harta bendamu) di jalan Allah, dan janganlah kamu menjatuhkan dirimu sendiri ke dalam kebinasaan, dan berbuat baiklah, karena sesungguhnya Allah menyukai orang-orang yang berbuat baik. (Qs. al-Baqoroh : 195).

Di dalam ayat tersebut perintah Allah s.w.t. untuk berbuat baik tidak Allah batasi obyeknya. Yang berarti kita diperintahkan untuk berbuat baik kepada siapa saja meskipun orang tersebut adalah orang yang kita benci. Dan termasuk perbuatan baik adalah memperlakukan orang lain dengan baik di dalam pergaulan sehari-hari tanpa membeda-bedakan mereka.

\section{Anda tidak sesuai dgn apa} yang Anda katakan

Poin berikut ini sebenarnya sudah penulis jelaskan di dalam pembahasan keterampilan. Namun penulis menganggap poin ini juga mengandung konteks etika komunikasi islami sehingga penulis masukkan ke dalam etika komunikasi bergaul.

Setiap kita mungkin pernah menyelisihi perkataan kita sendiri. kita mungkin pernah menasihati orang lain untuk selalu berkata baik, namun ternyata kita sering berkata buruk. Itu berarti kita telah menyelisihi apa yang kita katakan. Hal tersebut persis seperti ungkapan kaum pinggiran orang banjar yang mengatakan "Jauh muntung pada burit", yang artinya melakukan perbuatan yang kita ingkari dengan lisan kita, atau tidak melakukan perbuatan yang kita anjurkan. 
Menyelisihi perkataan

sendiri sebenarnya adalah sesuatu yang amat dibenci oleh Allah s.w.t. sebagaimana dijelaskan di dalam firmannya yang berbunyi :

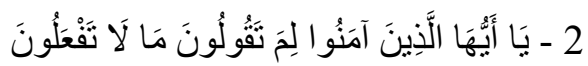

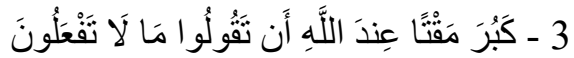

2 - Wahai orang-orang yang beriman, kenapakah kamu mengatakan sesuatu yang tidak kamu kerjakan?

3 - Amat besar kebencian di sisi Allah bahwa kamu mengatakan apa-apa yang tidak kamu kerjakan. (Qs. AsSaff : 2-3)

Maka dari itu kita sebagai hamba Allah yang selalu mendambakan kecintaan Allah kepada diri kita sangat perlu untuk menjauhi sikap menyelisihi perkataan sendiri ini agar kita tidak mendapatkan kebencian dari Allah s.w.t. yang akhirnya menghalangi kecintaannya kepada kita.
Sub ketegori etika komunikasi yang ke 5 adalah etika berunding. Ada 4 poin etika komunikasi yang termasuk ke dalam sub kategori etika berunding. Berunding berasal dari kata dasar runding. Di dalam kamus besar bahasa Indonesia kata berunding diartikan sebagai: bercakap-cakap (tentang suatu hal); berbicara; berembuk (http://kbbi.web.id/). Berunding merupakan bagian dari jenis komunikasi yang sering dilakukan oleh kelompok namun juga tidak menutup kemungkinan berunding juga dilakukan oleh dua orang saja. Kata berunding sering diidentikkan dengan pembicaraan yang dilakukan oleh dua orang atau kelompok yang saling bermusuhan yang hendak mencari jalan tengah agar tercapai perdamaian. Karena berunding juga bagian dari komunikasi maka kegiatan berunding juga memiliki aturan-aturan yang mengaturnya agar berjalan dengan baik yaitu etika komunikasi berunding.

\section{Etika berunding}


a. Bersikap santun dan sopan terhadap musuh

Sikap santun dan sopan adalah salah satu etika komunikasi dalam hal apa saja yang terdapat komunikasi di dalamnya, dan termasuk hal tersebut adalah berunding. Setiap muslim yang beriman kepada Allah s.w.t. diwajibkan baginya untuk bersikap sopan santun terhadap siapa saja, bahkan kepada musuh sekalipun. Maka dari itu ketika seseorang berunding dengan musuhnya dia tetap harus bersikap sopan santun.

Kecuali musuh tersebut membahayakan dirinya dan mungkin akan mendatangkan kerugian bagi dirinya maka boleh untuk bersikap tegas. Sikap sopan dan santun terhadap musuh ini telah dicontohkan oleh Rasulullah s.a.w. dalam setiap perundingan yang beliau lakukan. Meskipun musuh yang beliau hadapi adalah musuh yang paling jahat dan paling keras permusuhannya kepada beliau.
Beliau mampu untuk bersikap sopan tersebut adalah disebabkan rahmat Allah s.w.t. kepada beliau. Sebagaimana yang disebutkan Allah s.w.t. di dalam firmannya yang berbunyi

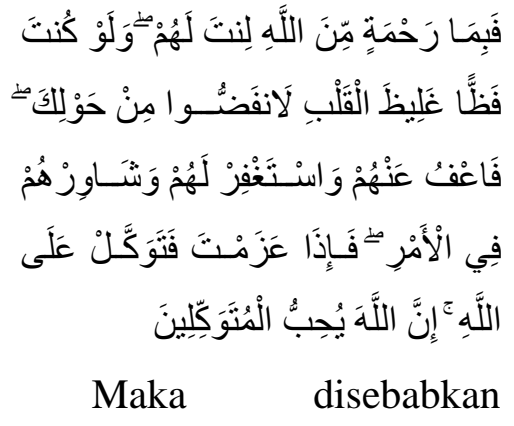

rahmat dari Allah-lah kamu berlaku lemah lembut terhadap mereka. Sekiranya kamu bersikap keras lagi berhati kasar, tentulah mereka menjauhkan diri dari sekelilingmu. Karena itu maafkanlah mereka, mohonkanlah ampun bagi mereka, dan bermusyawaratlah dengan mereka dalam urusan itu. Kemudian apabila kamu telah membulatkan tekad, maka bertawakkallah kepada Allah. Sesungguhnya Allah menyukai orang-orang yang bertawakkal kepada-Nya. (Qs. Ali Imron : 159) 
Rasulullah s.a.w. adalah contoh yang sempurna di dalam segala hal, beliau adalah kompas hidup kita dan pemandu perjalanan hidup kita. Maka dari itu kita harus selalu menjadikan beliau sebagai idola kita yang kita ikuti segala tindak tanduknya.

\section{b. Mengatakan perkataan yang} baik kepada musuh

Ungkapan qaulan ma'rufa, jika ditelusuri lebih dalam dapat diartikan dengan "ungkapan atau ucapan yang pantas dan baik". "Pantas" di sini juga bisa diartikan sebagai kata-kata yang "terhormat", sedangkan "baik" diartikan sebagai kata-kata yang “sopan”. 16 Qaulan Ma'rufa dapat diterjemahkan dengan ungkapan yang pantas. Kata ma'rufa berbentuk isim maf'ul yang berasal dari madhinya, 'arafa. Salah satu pengertian ma'rufa secara etimologis

${ }^{16}$ Wahyu Ilaihi, Komunikasi Dakwah, (Bandung: Remaja Rosda Karya, 2010), h. 183. adalah al-khair atau al-ihsan, yang berarti yang baik-baik. Jadi qaulan ma'rufa mengandung pengertian perkataan atau ungkapan yang baik dan pantas (Amir 1999, 85). Dalam Alquran ungkapan qaulan ma'rufa ditmukan dalam surah Al-Baqarah, 235, AlAhzab; 32, Al-Baqarah; 263, An-Nisaa; 5 dan 8. Dalam Alquran Q.S. al-Baqarah/263: 2. Allah berfirman:<smiles>C=CCCCCCCCCC</smiles>

Artinya: "Perkataan yang baik dan pemberian maaf lebih baik dari sedekah yang diiringi dengan sesuatu yang menyakitkan (perasaan si penerima). Allah Maha Kaya lagi Maha Penyantun". ${ }^{17}$

Perkataan yang baik di dalam perundingan tentunya akan membuat sebuah perundingan berjalan lancar dan menghasilkan kesepakatan yang

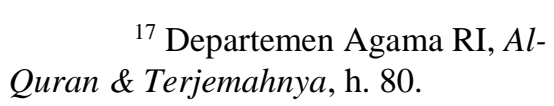

${ }^{17}$ Departemen Agama RI, AlQuran \& Terjemahnya, h. 80. 
menguntungkan bagi kedua belah pihak dan sangat mungkin akan menumbuhkan benihbenih perdamaian bagi kedua belah pihak tersebut.

c. Hindari kekasaran dan perkataan yang buruk terhadap musuh.

Perkataan buruk dan kasar adalah lawan dari perkataan yang baik. Apabila seorang muslim diwajibkan untuk selalu berkata baik, maka tentu ia dilarang untuk berkatakata kasar dan buruk. Termasuk yang dilarang adalah berkata buruk dan kasar ketika berunding dengan musuh. Sebagaimana yang dicontohkan oleh Rasulullah s.a.w., beliau tidak pernah berkata buruk dan kasar ketika berunding dengan musuh-musuh beliau dan beliau juga melarang umatnya untuk melakukan hal tersebut. Sebagaimana sebuah hadits yang berbunyi :

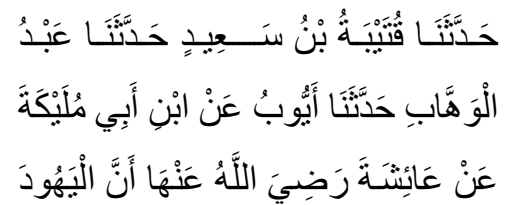

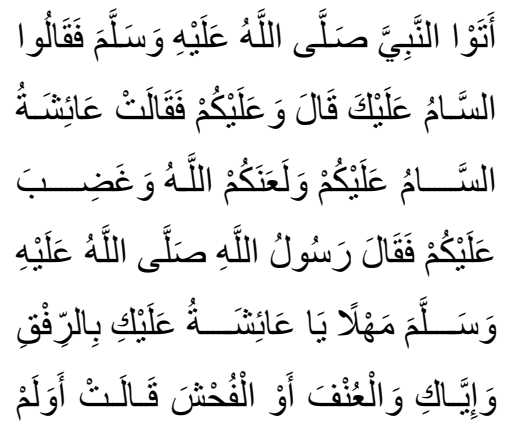

Telah menceritakan kepada kami Qutaibah bin Sa'id telah menceritakan kepada kami Abdul Wahhab telah menceritakan kepada kami Ayyub dari Ibnu Abu Mulaikah dari Aisyah radliallahu 'anha bahwa sekelompok orang Yahudi datang menemui Nabi shallallahu 'alaihi wasallam, lalu mereka mengucapkan; "As Saamu 'alaika Kebinasaan atasmu." Beliau menjawab: 'Wa 'alaikum Dan atas kalian juga.' Kemudian Aisyah berkata; 'As Saатu 'alaikum wala'anakumullah wa ghadziba 'alaikum Semoga kebinasaan atas kalian, dan laknat Allah serta murka Allah menimpa kalian.' Maka Rasulullah 
shallallahu 'alaihi wasallam bersabda: 'Pelan-pelan wahai Aisyah, hendaklah kamu berlemah lembut dan janganlah kamu kasar atau berkata keji.' Aku berkata; 'Apakah anda tidak mendengar apa yang diucapkan mereka? ' Beliau bersabda: 'Apakah kamu tidak mendengar ucapanku, sebenarnya aku tadi telah menjawabnya, maka do'aku atas mereka telah dikabulkan, sementara do'a mereka atasku tidak akan terkabulkan.' (HR. Bukhari)

Dari hadits tersebut
dapat kita pahami bahwa
Rasulullah sangat membenci
kata-kata kasar dan buruk, dan
melarang umatnya
mengucapkannya meskipun hal
tersebut diucapkan kepada
musuh.

Perkataan yang buruk di dalam perundingan tentunya juga akan membuat perundingan menjadi gagal dan sangat mungkin permusuhan akan semakin berkobar. d. Berlemah lembut terhadap musuh Berlemah lembut terhadap musuh adalah perintah dari Rasulullah s.a.w. kepada umatnya. Sebagaimana sabda beliau yang berbunyi :

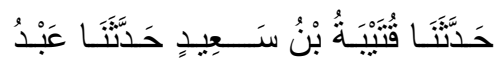

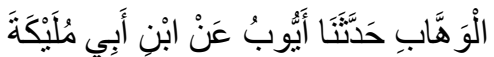

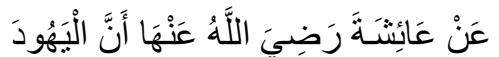

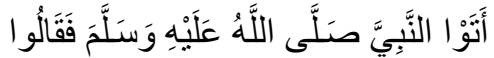

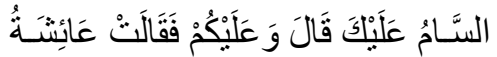

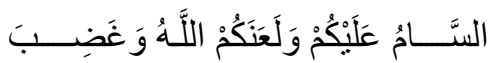

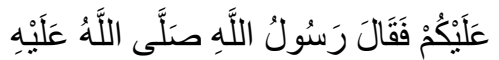

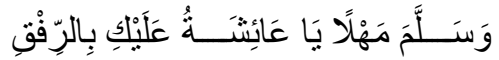

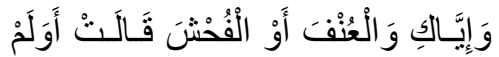

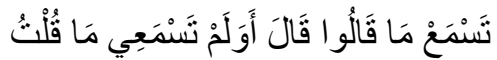

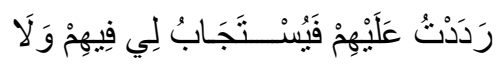

$$
\begin{aligned}
& \text { يُسنتَجَابُ لَهُمْ فِيَّة }
\end{aligned}
$$

Telah menceritakan kepada kami Qutaibah bin Sa'id telah menceritakan kepada kami Abdul Wahhab telah menceritakan kepada kami Ayyub dari Ibnu Abu Mulaikah dari Aisyah radliallahu 'anha bahwa sekelompok orang Yahudi datang menemui Nabi shallallahu 'alaihi wasallam, lalu mereka mengucapkan; "As 
Saamu 'alaika Kebinasaan atasmu." Beliau menjawab: 'Wa 'alaikum Dan atas kalian juga.' Kemudian Aisyah berkata; 'As Sаати 'alaikum wala'anakumullah wa ghadziba 'alaikum Semoga kebinasaan atas kalian, dan laknat Allah serta murka Allah menimpa kalian.' Maka Rasulullah shallallahu 'alaihi wasallam bersabda: 'Pelan-pelan wahai Aisyah, hendaklah kamu berlemah lembut dan janganlah kamu kasar atau berkata keji.' Aku berkata; 'Apakah anda tidak mendengar apa yang diucapkan mereka? ' Beliau bersabda: 'Apakah kamu tidak mendengar ucapanku, sebenarnya aku tadi telah menjawabnya, maka do'aku atas mereka telah dikabulkan, sementara do'a mereka atasku tidak akan terkabulkan.' (HR. Bukhari).

Dari hadits tersebut dapat kita pahami bahwa berlemah lembut adalah sebuah perintah Rasulullah s.a.w. yang harus kita kerjakan jika kita mengaku sebagai umat beliau dan mencintai beliau sepenuh hati.

Apabila kita mampu berlemah lembut di dalam berunding dengan musuhmusuh kita, maka kemungkinan musuh-musuh kita akan mengendurkan permusuhannya kepada kita sehingga perdamaian akan dapat dicapai.

\section{Etika Menasihati}

Ada 10 poin etika komunikasi Islami yang termasuk sub kategori etika menasihati, 3 diantaranya penulis analisis sebagai berikut:

\section{a. Bersikap sopan santun ketika} menegur sesuatu kejelekan

Di dalam setiap kegiatan komunikasi kita, sopan santun adalah sikap yang tidak boleh ditinggalkan sedikitpun. Karena tanpa sikap sopan santun suatu komunikasi akan menjadi komunikasi yang tidak etis. Hendaknya kita menegur mereka dengan sopan santun dan kelembutan. 
Sebagaimana junjungan

kita Nabi Muhammad s.a.w. selalu menasihati sahabatnya dengan sopan santun. Sebagaimana diceritakan di dalam sebuah hadits yang berbunyi :

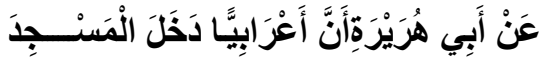

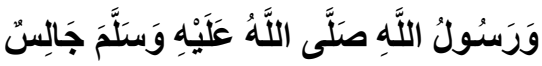

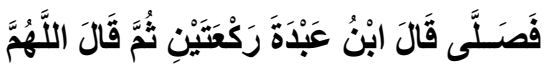

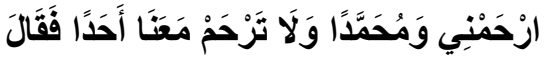

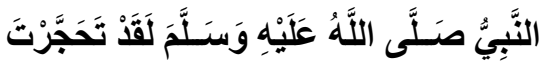

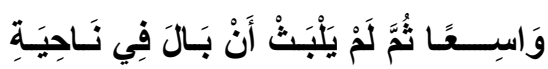

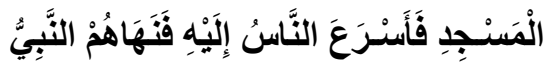

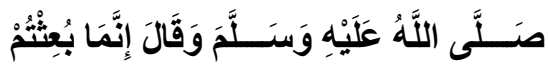

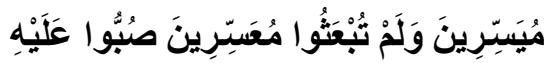

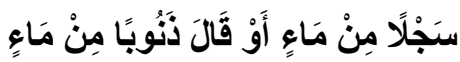

Dari Abu Hurairah RA, bahwasanya pernah ada seorang Arab badui masuk ke dalam masjid, sedangkan Rasulullah SAW duduk, lalu orang tersebut mengerjakan shalat, kata Ibnu Abdah, "Dua rakaat" kemudian berkata (orang itu), "Ya Allah! Berilah aku rahmat dan Muhammad, dan janganlah engkau beri rahmat seseorang yang bersama kami!" Maka Rasulullah SAW bersabda,
"Sesungguhnya kamu telah mempersempit suatu perkara yang luas. " Kemudian orang itu tetap tinggal, sehingga kencing di sudut masjid. Maka orang-orang dengan segera membentaknya, lalu Nabi SAW melarang mereka dan bersabda, "Sesungguhnya kamu sekalian diutus untuk mempermudah, tidak diutus untuk mempersulit. " Tuangkanlah air satu timba ke atas kencing itu!" (HR. Bukhari).

\section{b. Bertutur katalah yang baik}

Ketika menasihati kesalahan orang lain hedaknya kita menggunakan perkataan yang paling baik yang mampu kita ucapkan. Sehingga orang yang kita nasihati tidak tersinggung dan merasa digurui. Perkataan baik tentunya akan membuat nasihat lebih mengena dan meresap ke dalam hati orang yang dinasihati dan memunculkan kesadaran untuk memperbaiki kesalahan tersebut. Selain itu Allah s.w.t. juga telah memerintahkan 
kepada hambanya agar selalu berkata baik kepada siapa saja dan kapn saja. Sebagaimana yang tertulis di dalam firmanNya yang berbunyi :

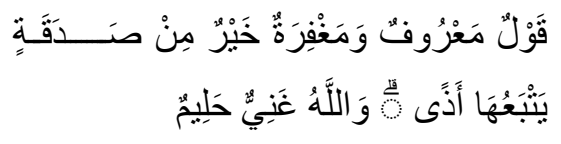

Artinya: "Perkataan yang baik dan pemberian maaf lebih baik dari sedekah yang diiringi dengan sesuatu yang menyakitkan (perasaan si penerima). Allah Maha Kaya lagi Maha Penyantun”. (Qs. alBaqarah : 263).

Dari ayat tersebut dapat kita fahami bahwa Allah s.w.t. menganjurkan kepada kita untuk berkata baik dan memaafkan kesalahan orang lain.

Ketika orang lain melakukan kesalahan di hadapan kita, maka sudah menjadi kewajiban kita untuk menasihati orang tersebut dengan perkataan yang baik dan apabila kesalahan tersebut menyangkut diri kita maka akan lebih baik jika kita segera memaafkan kesalahan orang tersebut.

\section{c. Jangan suka mencela ketika menasihati}

Setiap orang pasti tidak senang ketika dicela. oleh karena itu janganlah kita suka mencela orang lain, apalagi ketika menasihati seseorang. Karena nasihat yang diikuti dengan celaan maka akan membuat nasihat tersebut tidak berbekas dan bahkan membuat marah orang yang dinasihati.

Kita tidak boleh mencela orang lain karena bisa saja orang yang kita cela ternyata lebih baik dari diri kita. selain itu sebelum mencela orang lain, bayangkanlah bila kita yang berada di posisi orang yang akan kita cela tersebut. Tentunya kita akan merasa sakit hati dan tersinggung berat. Oleh karena itu ketika kita menasihati orang lain hendaknya tidak mencela habis-habisan kesalahan orang tersebut dan berusaha untuk bersikap adil dan memfokuskan nasihat pada 
hal-hal baik yang dilakukan oleh orang tersebut. Selain itu suka mencela orang lain adalah sesuatu yang dilarang oleh Allah s.w.t. sebagaimana firman-Nya yang berbunyi :

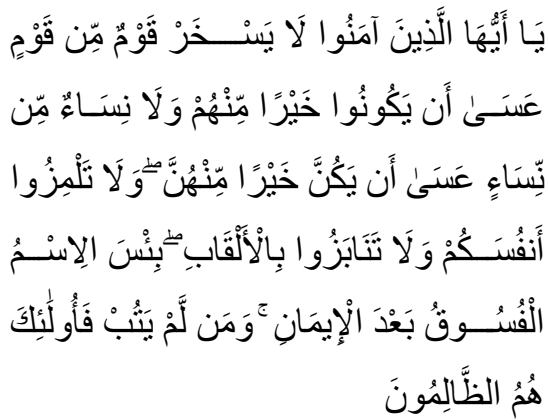
Hai orang-orang yang beriman, janganlah sekumpulan orang laki-laki mencela kumpulan yang lain, boleh jadi yang dicela itu lebih baik dari mereka. Dan jangan pula sekumpulan perempuan mencela kumpulan lainnya, boleh jadi yang dicela itu lebih baik. Dan janganlah suka mencela dirimu sendiri dan jangan memanggil dengan gelaran yang mengandung ejekan. Seburuk-buruk panggilan adalah (panggilan) yang buruk sesudah iman dan barangsiapa yang tidak bertobat, maka mereka itulah orangorang yang zalim.
Dari ayat tersebut dapat dipahami bahwa mencela orang lain adalah sesuatu yang buruk untuk dilakukan. Sehingga kita wajib menghindari perilaku suka mencela orang lain apalagi melakukannya ketika kita menasihati orang lain.

\section{Etika berdebat}

Berdebat adalah salah satu bentuk kegiatan komunikasi. Di dalam perdebatan ada suatu hal yang diperdebatkan disebabkan perbedaan pendapat dalam hal tersebut sehingga berdebat digunakan sebagai sarana beradu argumen untuk mencari siapa yang lebih mendekati kebenaran.

Sebenarnya perdebatan adalah sesuatu yang dilarang di dalam Islam. Perdebatan yang dilarang adalah perdebatan dengan sesama muslim. Sedangkan perdebatan yang diperbolehkan adalah perdebatan seorang muslim dengan seorang di luar agama Islam. Sebagaimana sabda Rasulullah s.a.w. yang berbunyi : 


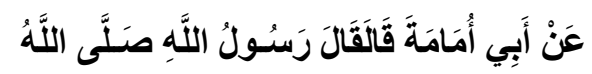

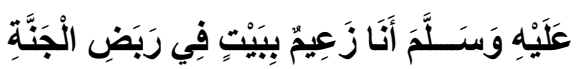

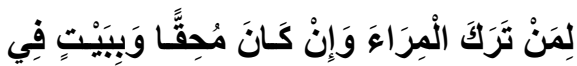

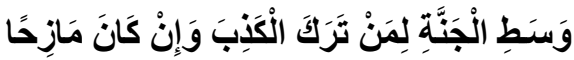

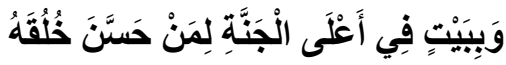

Dari Abu Umamah, ia berkata, "Rasulullah SAW bersabda, Aku dapat menjamin sebuah rumah di kebun surga untuk orang yang meninggalkan perdebatan meskipun ia benar. Dan (menjamin sebuah rumah) di pertengahan surga bagi orang yang tidak berdusta meskipun bergurau. Dan (menjamin sebuah rumah) di bagian yang tinggi dari surga bagi orang yang baik budi pekertinya'. "(HR. Bukhari).

\section{Ketika seseorang} berdebat, maka ia harus mengikuti etika yang berlaku. Terutama etika yang ditetapkan oleh agama Islam.

\section{a.Jangan berdebat dalam keadaan marah}

Nafsu amarah biasanya tidak muncul begitu saja, tentu adal hal-hal yang memicunya. Salah satu yang memicu munculnya nafsu amarah adalah perdebatan. Karena di dalam perdebatan ada perbedaan pendapat dan kecendrungan mempertahankan pendapat tersebut dengan segala cara. Sehingga ketika perbedaan pendapat di dalam perdebatan tidak menemukan titik temu, maka akhirnya perdebatan memanas, masing-masing pihak bersikeras dengan pendapatnya masing-masing sehingga suara mulai meninggi, emosi mulai muncul, kemudian darah mendidih sampai ke ubun-ubun dan berubah menjadi nafsu amarah, dan akhirnya terjadilah sesuatu yang seharusnya tidak terjadi sehingga memperparah keadaan dan memperluas jurang perbedaan.

Islam menganjurkan umatnya untuk tidak mudah marah. Namun apabila rasa marah itu sudah muncul maka Islam mengharuskan umatnya mengendalikan marah tersebut. Sebagaimana sabda Rasulullah s.a.w. yang berbunyi : 


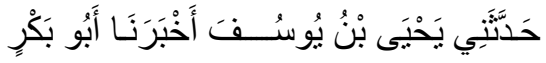

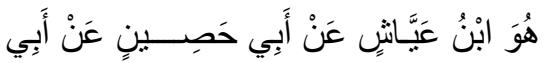

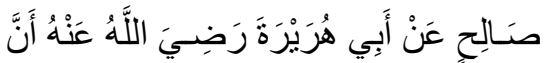

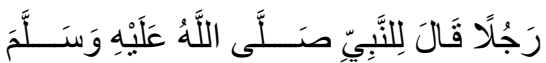

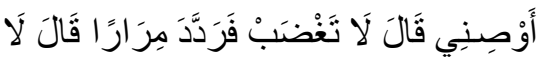
تَغْضْنَبْن

Telah menceritakan kepadaku Yahya bin Yusuf telah mengabarkan kepada kami Abu Bakr yaitu Ibnu Ayyasy dari Abu Hashin dari Abu Shalih dari Abu Hurairah radliallahu 'anhu bahwa seorang laki-laki berkata kepada Nabi shallallahu 'alaihi wasallam; "Berilah aku wasiat?" beliau bersabda: "Janganlah kamu marah." Lakilaki itu mengulangi katakatanya, beliau tetap bersabda: "Janganlah kamu marah."(HR. Bukhari)

Dan di dalam hadits yang lain beliau bersabda :

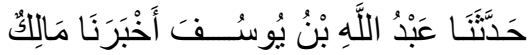
عَنْ ابْنِ شِهَهابِ عَنْ سَعِيِد بْنِ الْمُسَيَّبِ عَنْ

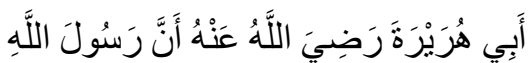

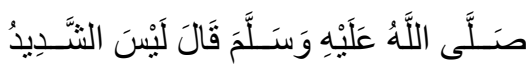

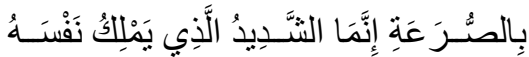
عنْدَ الْغَضَب
Telah menceritakan kepada kami Abdullah bin Yusuf telah mengabarkan kepada kami Malik dari Ibnu Syihab dari Sa'id bin Musayyib dari Abu Hurairah radliallahu 'anhu bahwa Rasulullah shallallahu 'alaihi wasallam bersabda: "Tidaklah orang yang kuat adalah orang yang pandai bergulat, tapi orang yang kuat adalah orang yang dapat menahan nafsunya ketika ia marah."(HR. Bukhari)

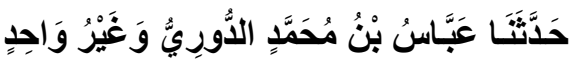

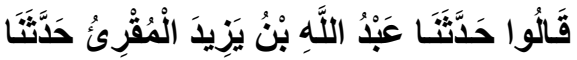

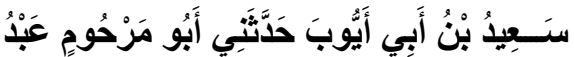

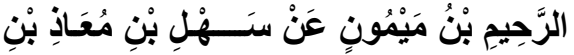

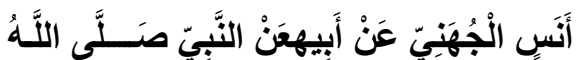

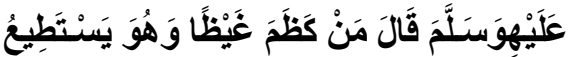

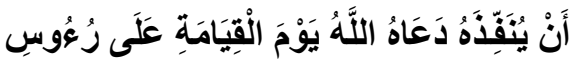

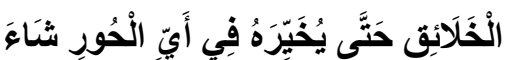
Abbas bin Muhammad Ad-Duri dan yang lainnya menceritkan kepada kami dan mereka berkata, Abdullah bin Yazid Al Muqri menceritkan kepada kami, Sa'id bin Abu Ayyub menceritkan kepada kami, $\quad$ Abu Marhum 
Abdurrahim bin Maimun menceritkan kepadaku, dari Sahl bin Mu'adz bin Anas Al Juhani dari bapaknya, bahwa Nabi SAW bersabda, "Barangsiapa yang menahan marah sedang ia mampu untuk melampiaskannya, maka Allah akan memanggilnya pada hari kiamat di hadapan para makhluk, sehingga Allah akan memilihkan untuknya bidadari mana yang ia inginkan ".(HR. Tirmidzi).

Termasuk halnya ketika kita sedang berdebat dengan seseorang yang kata-katanya memancing kemarahan kita. maka kita harus ingat anjuran Rasulullah s.a.w. untuk menahan marah, dan kemudian mengingat-ingat ganjaran yang besar apabila kita mampu menahan rasa marah yang kita alami. Ketika mampu berdebat tanpa rasa marah sedikit pun, maka perdebatan kita akan lebih bermanfaat dan memberikan hasil yang baik. b. Berdebatlah dengan santun dan lemah lembut

Sebelumnya telah dijelaskan etika berdebat yang pertama yaitu dengan mengendalikan diri untuk tidak marah. Maka etika berdebat yang kedua ini adalah upaya untuk menghindari pemicu kemarahan dan mendinginkan kemarahan yang terlanjur muncul, yaitu berdebat dengan cara yang santun dan lemah lembut.

Penulis telah menjelaskan banyak hal pada pembahasan sebelumnya mengenai kesantunan dan keramahan. Penjelasan untuk poin etika berikut ini juga kurang lebih sama dengan penjelasan pada pembahasan sebelumnya. Yang membedakan hanyalah bentuk kegiatannya saja yang pada poin berikut ini adalah kegiatan berdebat.

$\begin{array}{llr} & \text { Kegiatan berdebat } \\ \text { sangat memerlukan sikap } & \text { lembut, } \\ \text { santun dan lemah lem } & \text { karena dengan dua sikap }\end{array}$


tersebut, kemarahan akan dapat diredam dan komunikasi akan berjalan lebih hangat. Ketika perdebatan dilakukan dengan santun dan lemah lembut maka pada perdebatan tersebut akan muncul sikap toleransi yang akhirnya menyebabkan perdebatan berakhir damai meskipun pendapat tidak bisa disatukan.

Oleh karena itu kita harus selalu membiasakan sikap santun dan lembut di dalam segala hal termasuk di dalamnya berdebat. Sehingga sikap santun dan lemah lembut tersebut menjadi kebiasaan yang sangat mudah dilakukan pada hal-hal lainnya. Selain itu Rasulullah s.a.w. telah mengharuskan kepada kita untuk selalu berlemah lembut dalm segala hal. Sebagaimana sabda beliau yang berbunyi :

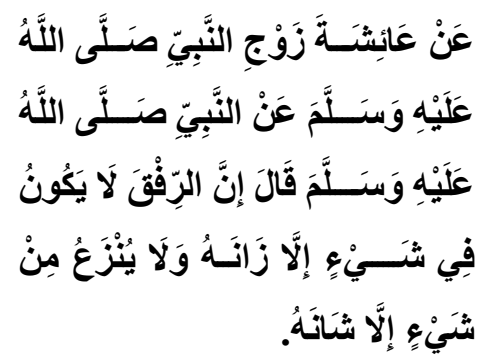

Dari Aisyah RA -istri Rasulullah SAW- Rasulullah telah bersabda, "Sesungguhnya lemah lembut itu tidak akan berada pada sesuatu melainkan ia akan menghiasinya \{dengan kebaikan\}. Sebaliknya, jika lemah lembut itu dicabut dari sesuatu, melainkan ia akan membuatnya menjadi buruk." (HR. Muslim).

\section{Simpulan}

Setelah peneliti menyajikan temuan data dari buku Enjoy Your Life karya Dr. Muhammad Al Areifi serta menganalisa subkategori keterampilan komunikasi islami antarpribadi dan subkategori etika komunikasi islami antarpribadi sekaligus beberapa poin di dalamnya, maka penulis mengambil beberapa kesimpulan sebagai berikut:

1. Berdasarkan hasil penelitian dapat diketahui bahwa kategori keterampilan komunikasi islami antarpribadi di dalam buku Enjoy Your Life karya Dr. Muhammad Al Areifi terdiri dari 11 Subkategori, yaitu: Keterampilan 
persiapan komunikasi yang terdiri dari 34 poin, keterampilan berjumpa yang terdiri dari 8 poin, keterampilan mendengarkan yang terdiri dari 3 poin, keterampilan mengakrabkan yang terdiri dari 15 poin, keterampilan memengaruhi terdiri dari 7 poin, keterampilan menyenangkan hati orang lain terdiri dari 39 poin, keterampilan menjaga perasaan orang lain terdiri dari 32 poin, keterampilan pengendalian diri terdiri dari 48 poin, keterampilan penyesuaian diri terdiri dari 49 poin, keterampilan memperbaiki kesalahan terdiri dari 51 poin, keterampilan membentuk citra diri terdiri dari 7 poin, jika dijumlahkan secarakeseluruhan keterampilan komunikasi islami antarpribadi yang penulis temukan semuanya berjumlah 290 poin keterampilan komunikasi islami antarpribadi.

2. Kategori etika komunikasi islami antarpribadi di dalam buku Enjoy Your Life karya Dr. Muhammad Al Areifi terdiri dari 7 subkategori Etika, yaitu: Etika berjumpa terdiri dari 9 poin, etika mengajak terdiri dari 3 poin, etika berbicara terdiri dari 36 poin, etika bergaul terdiri dari 47 poin, etika berunding terdiri dari 4 poin, etika menasihati terdiri dari 10 poin, etika berdebat terdiri dari 2 poin, jika dijumlahkan secara keseluruhan etika komunikasi islami antarpribadi yang penulis temukan di dalam buku Enjoy Your Life karya Dr. Muhammad Al Areifi semuanya berjumlah 111 poin etika komunikasi.

3. Setelah melakukan penelitian mendalam terhadap buku Enjoy Your Life karya Dr. Muhammad Al Areifi, penulis menyimpulkan bahwa buku tersebut memang sarat dengan nilai-nilai keterampilan dan etika komunikasi islami antarpribadi sebagaimana asumsi penulis.

\section{Daftar Pustaka}

Departemen Agama RI, Al-Quran \& Terjemahnya.

http://shannonweaverppmb2013.blogspot.co.id/201 3/09/keterampilankomunikasi-communication, diakses tanggal 16 November 2016. 
http://kbbi.web.id/runding diakses tanggal 9-04-2017.

Ilaihi, 2010. Komunikasi Dakwah, Bandung: Remaja Rosda Karya.

Mulyana,2011 Ilmu Komunikasi. Cet ke 15, Bandung: PT Remaja Rosdakarya.
Said. 2014. 101 Hadits Budi Luhur. cet. Kelimapuluhsatu, Bandung: Putra. Alma'arif.

Supratiknya, 1995. Komunikasi Antarpribadi. Cetakan kedelapan. Yogyakarta: Kansius.

Suranto Aw, 2011Komunikasi Interpersonal. cet. Pertama, Yogyakarta: Graha Ilmu. 